\title{
YOU ARE NOT THE FIRST MINION TO DISAPPOINT ME
}

\author{
It's just so difficult to get the staff these days.
}

\section{BY IAN CREASEY}

$\mathrm{Y}$ ou have let me down. Your task was simple! You were supposed to distract Captain Nebulon and lure him into the Shadow Zone, where our phantoms could have toyed with him for years. Now he has slipped your grasp, and he reaches ever closer to the Neutronic Modulator.

You are not the first minion to disappoint me. I'm sure you recall what happened to your predecessor - you oversaw his fate yourself. We always need fresh brains for the Monster Pit.

How could you be so careless? Don't you realize the importance of our scheme? We must obtain the Neutronic Modulator so that we can unlock the wormhole, solve the self-erasing paradox, defeat the Masters of Entropy, and thereby put the governance of the galaxy on a firmer foundation.

I expected so much more from you. Because my previous subordinates had been consistently inept, I employed special measures in your case. I decided that as other people were invariably disappointing, the only person I could rely upon was myself. And so I created you from my own flesh and blood.

Well, flesh. I have very little blood left, after replacing it with athanatic serum. Cancer cells are immortal, so I turned myself into a giant tumour. Eternity is worth a few side effects. My teratogenic outgrowths are mostly non-functional, rarely causing much disturbance outside the nightmares of my enemies. And although I depend upon a constant infusion of fresh serum, I'm careful to maintain back-up systems in case of any interruption to my supply.

I ramble, I know. It is the only way I can hear an intelligent word spoken in the depths of my lair. Certainly I hear little wisdom from you. Even now, you merely cower in front of me, with a vacant expression on your face. I would like to see a little more ambition. When I say "You are not the first minion to disappoint me", I almost wish you would interrupt and say, "But I shall be the last!"

I've told you before how I overthrew my

DNATURE.COM

Follow Futures:

y @NatureFutures

$f$ go.nature.com/mtoodm predecessor. Whenever he doubted my loyalty, he used to lecture me on the perils of leadership: "This

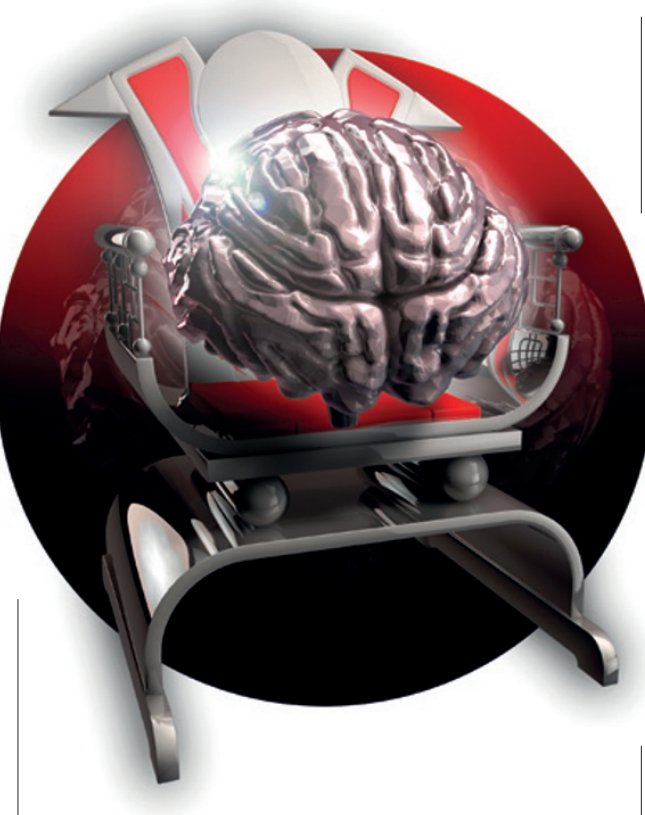

spiky titanium throne is not as comfortable as it looks. Being the Hyper-Dimensional Overlord is an endless series of frustrations. Inadequate minions are not the only source of disappointment, I can assure you."

Yet he appreciated my eagerness to concoct new plots rather than merely follow directions. When I deposed him, he admired the efficiency of my coup. I know, because his wraith still haunts this throne and offers me advice.

He always said that you lacked the drive to be a truly cunning henchman. Right now, he is urging me to dispose of you. Perhaps I shall, after I've finished explaining all the ways in which you have disappointed me.

Let's see... what else is there? You have chosen an incompetent underling, again. Your latest deputy is not as good at slinking undetected as he believes. Slinking is an important skill, one that the younger generation neglects.

You have barely spent any time in the Monster Pit, not even to ride the Chrome Leopards or ingratiate yourself with the Brain Worms. You must feed the Zaptors with your own hands, or you can hardly expect them to snap and snarl when you wish to impress a hostage with their ferocity.

You -

Wait! There is a disturbance in the dungeons. Someone has breached the perimeter of my back-up vault. Is it Captain Nebulon already? I thought he was busy questing for the Neutronic Modulator. We shall deal with him soon enough, when I have finished reprimanding you. As you seem unable to execute my schemes, perhaps you would like to suggest your own plan for dealing with him?

Speak up! Don't just slump with your jaw gaping. The appropriate time to gape your jaw is when you're terrorizing a victim by displaying your metallic fangs. And you haven't even installed metallic fangs yet. That's yet another sign of your -

Ouch! What's happening? The fresh serum is burning me. Aaargh! What have you done, you fool?

Oh, I see. You've projected a hologram. Your image has been receiving my rebuke, while you silently sneaked behind me and poisoned my supply of athanatic serum. It's about time! I'm glad to see you finally showing some initiative.

\section{Uuuuurck. Blarvle. Kkkksss.}

Those are not my last words: I would have uttered something more eloquent. You have succeeded in killing my body, but your deputy has failed to destroy my back-up systems. He blundered around the dungeons without penetrating the inner vault. Inside the necrocomputer, my brain patterns persist. Their output is routed to a panel built into this titanium throne.

Step forward! Switch off the hologram, and reveal yourself. Remove my carcass: its ugliness is offensive. I will permit you to kick it, if you like, but only once. Seat yourself upon the throne, and enjoy your ascent. I look forward to my new advisory role.

You have already learned the frustrations of relying on others to perform crucial assignments. Your first duty as the new HyperDimensional Overlord will be to rebuke your incompetent underling for failing to implement his part of your scheme. Bring him in here. Then repeat after me: "You have let me down. Your task was simple! You are not the first minion to disappoint me..."

Ian Creasey lives in Yorkshire, England. His stories have appeared in Asimov's Science Fiction and elsewhere, and his collection Maps of the Edge was published in 2011. 